\title{
Ecosystem services are lost when facilitation between two ecosystem engineers is compromised by oil
}

\author{
Sean P. Powers ${ }^{1, *}$, Shahrokh Rouhani ${ }^{2}$, Mary C. Baker ${ }^{3}$, Henry Roman ${ }^{4}$, \\ Jonathan H. Grabowski ${ }^{5}$, Steven B. Scyphers ${ }^{5}$, Jonathan M. Willis ${ }^{6}$, Mark W. Hester ${ }^{6}$ \\ ${ }^{1}$ Department of Marine Sciences, University of South Alabama and the Dauphin Island Sea Lab, 101 Bienville Blvd., \\ Dauphin Island, AL 36528, USA \\ ${ }^{2}$ NewFields, Inc., 1349 W. Peachtree Street, Suite 2000, Atlanta, GA 30309, USA \\ ${ }^{3}$ National Oceanic and Atmospheric Administration, Assessment and Restoration Division 7600 Sand Point Way NE, Seattle, \\ WA 98115, USA \\ ${ }^{4}$ Industrial Economics, Inc., 2067 Massachusetts Ave., Cambridge, MA 02140, USA \\ ${ }^{5}$ Marine Science Center, Northeastern University, 430 Nahant Road, Nahant, MA 01908, USA \\ ${ }^{6}$ Department of Biology, University of Louisiana, Lafayette, LA 70504, USA
}

\begin{abstract}
Nearshore marine ecosystems are among the most productive areas in the world. Unfortunately, these areas also receive pollutants released into oceanic and riverine waters. Six years following the Deepwater Horizon oil spill, the largest in US history, the complexity of ecological injuries in this system is just now being elucidated. Here, we describe a novel pathway of injury from oil spills by documenting how the loss of oysters near marsh edge as a direct result of shoreline oiling and clean-up activities can double rates of coastal erosion. As part of the natural resource damage assessment, we examined the impact of shoreline oiling on eastern oysters Crassostrea virginica near the marsh edge at 187 sites in Louisiana and Mississippi Sound in 2013. For marshes that experienced heavy oiling, oyster habitat was $77 \%$ less abundant than in areas where no oil was observed. Areas near marshes characterized by more moderate levels of oiling had $33 \%$ less oyster habitat than areas where no oil was observed. Similarly, the number of sites without any oyster habitat was higher in heavily and persistently oiled areas compared to areas where no oil was observed ( 56 vs. $24 \%$ ). The consequences of this loss are substantial and include loss of essential fish habitat, reduced nutrient cycling, and decreased erosion buffering. For a subset of the sites where erosion rate was also measured between 2010 and 2013 (n = 79), shoreline loss was more than twice as high ( 2.1 vs. $\left.0.9 \mathrm{~m} \mathrm{yr}^{-1}\right)$ in areas lacking oyster cover. Our findings provide evidence that loss of nearshore oyster habitat can disrupt the strong facilitation between oysters and marsh vegetation.
\end{abstract}

KEY WORDS: Marsh · Oysters · Facilitation - Natural resource damage assessment $\cdot$ Sustainability · Crassostrea virginica $\cdot$ Deepwater Horizon

\section{INTRODUCTION}

Within marine and estuarine landscapes, transition areas between habitat types ('edges') have extremely high biological production, serve as key nursery habitats for juvenile fish and mobile invertebrates, and are hotspots of biogeochemical cycling (Beck et

${ }^{*}$ Corresponding author: spowers@disl.org al. 2001, Bologna \& Heck 2002, Piehler \& Smyth 2011). The high biological productivity of these systems results from their juxtaposition between the end of the terrestrial biome and beginning of the sea. Shallow water $(<1 \mathrm{~m}$ depth) habitats adjacent to sandy shorelines and salt marshes are the most common habitat edges in estuaries of the northern Gulf of 
Mexico (GoM). These nearshore habitats also represent one of the more sensitive and imperiled systems in the world (Vitousek et al. 1997, Lotze et al. 2006, Halpern et al. 2007). Sea level rise, reduced sediment load of riverine systems as a result of upstream flood control measures, urban and agricultural development, and contamination threaten the existence of these habitats and the ecosystem services they provide to society (Vitousek et al. 1997, Syvitski et al. 2005). Because these areas account for $24 \%$ of total global ecosystem services (Costanza et al. 1997, 2014), the economic consequences of habitat losses can be staggering.

Unfortunately, nearshore habitats are often the final repository for contaminants released into oceans. Oil spills are one of the primary examples of this phenomenon, with sandy shores, rocky intertidal zones, seagrass meadows, and marsh edge habitats shown to accumulate oil transported by surface waters (e.g. Ixtoc I, Tunnell et al. 1981; 'Exxon Valdez,' Peterson et al. 2003; Persian Gulf War, Gundlach et al. 1993; see also NRC 2003). Oiling of these shorelines results in ecological
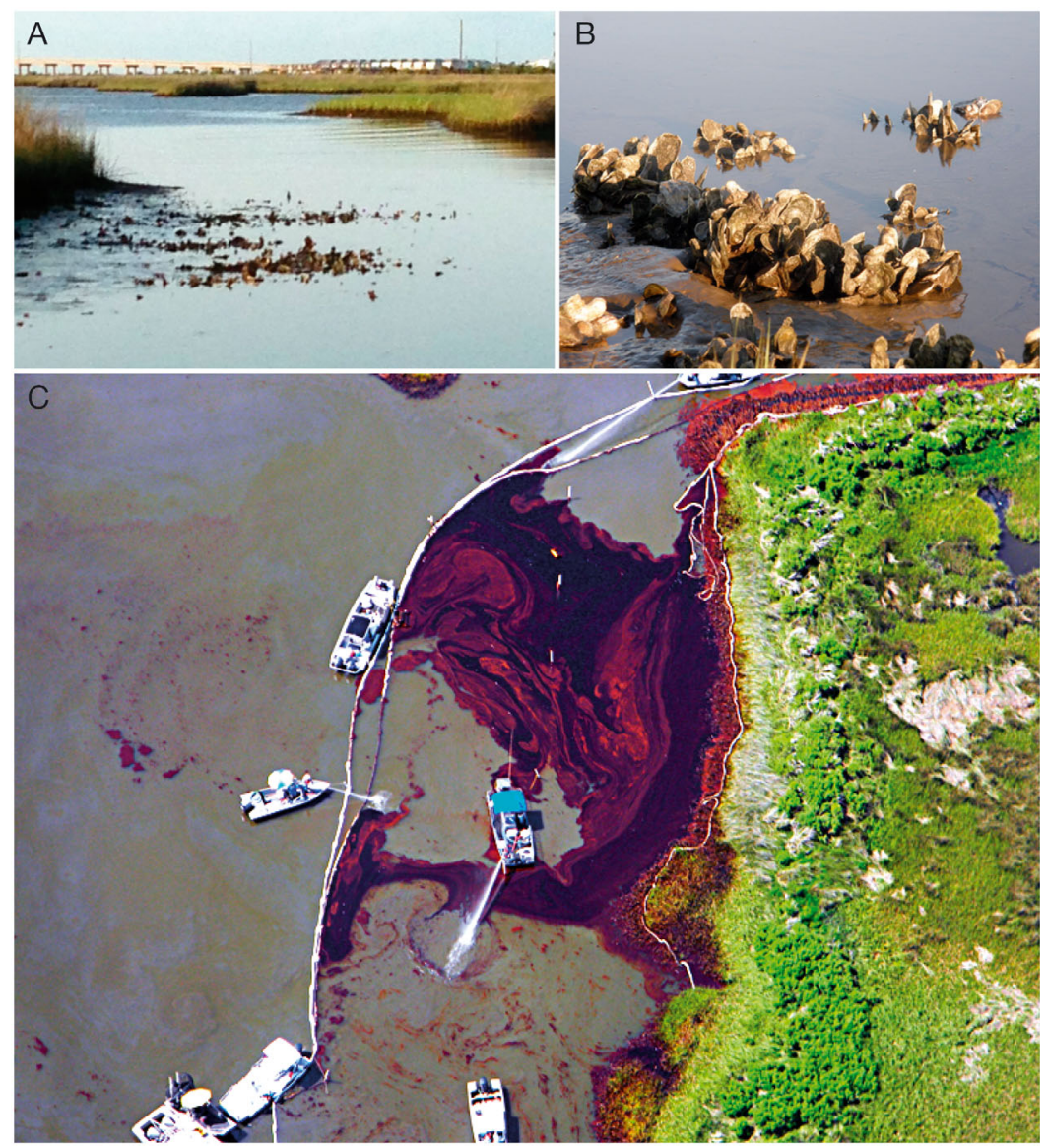

Fig. 1. (A) Nearshore intertidal eastern oysters Crassostrea virginica. (B) Typical oyster clump (hummock) along the shoreline. (C) Oiled shoreline injury via multiple pathways: (1) physical fouling and smothering of the sensitive plants and animals that serve as the foundational species for the habitat (Smith et al. 1984, Peterson et al. 2003); (2) toxicity of the oil to plants and animals (Roth \& Baltz 2009), which may last for extended periods of time if oil accumulates in bottom sediments or on marsh terrace soils (Reddy et al. 2002); and (3) oiled areas are also often the site of intensive response activities, which may result in physical degradation of the habitat (Driskell et al. 2001).

Whereas the ecological injuries associated with oiling vegetated and rocky intertidal shorelines are well established, less well-known is the response of eastern oysters Crassostrea virginica that form emergent reefs or smaller hummocks near marsh edges (Fig. 1). Historically, this narrow band of oysters along the marsh edge has largely been overlooked by marine resource agencies in the GoM and most of the Atlantic States (except South Carolina) because of the limited fishery value of the resource (Dyer \& Leard 1994). Oysters present in this zone are not con-

sidered desirable resources for the raw oyster market because of their irregular shape; they are difficult to harvest in the very shallow and soft sediment environments; and they often occur in areas closed to harvest because of water quality concerns (e.g. fecal coliforms, Vibrio spp.). The unattractiveness of these oysters for the fishery may increase their ecological importance, because in many areas these oysters serve as de facto sanctuary areas that form spawning stock reserves for oysters.

In contrast to their limited fishery value, the ecological importance of these oysters cannot be overstated. Nearshore oysters, like their subtidal counterparts, play in an important ecological role through their filtration activities. Oysters remove sediments, phytoplankton, and detrital particles, potentially reducing turbidity and improving water quality (Dame \& Patten 1981). The enhanced benthicpelagic coupling that results from the suspension feeding of dense assemblages of bivalves can create hotspots of biogeochemical cycling (Piehler \& Smyth 
2011, Kellogg et al. 2013) within the estuarine landscape. The complex habitat formed by the gregarious settlement of oysters (reefs or hummocks) also provides critical refuge for benthic invertebrates as well as fishes and mobile crustaceans (Meyer \& Townsend 2000, Peterson et al. 2003, Coen et al. 2007, Grabowski \& Peterson 2007). The complex structure provided by oyster habitat may also facilitate (sensu Bruno et al. 2003) the maintenance and expansion of other habitats. Shallow subtidal and intertidal oyster reefs can facilitate emergent (saltmarsh, Meyer et al. 1997, Scyphers et al. 2011) and submerged vegetation (seagrass, Newell et al. 2002) in estuarine systems. For emergent shoreline vegetation like Spartina patens and $S$. alterniflora, nearshore oyster habitat may reduce wave energy that would normally result in shoreline erosion (Meyer et al. 1997, Piazza et al. 2005, Scyphers et al. 2011, NRC 2014, Lunt et al. 2017).

Recognizing both the importance of nearshore oyster habitat and the substantive degree of shoreline oiling that resulted from the Deepwater Horizon (DWH) oil spill in the north-central GoM, we designed a large-scale study that examined the distribution and fate of oyster habitat as a function of severity of shoreline oiling at 187 sites from Terrebonne Bay, Louisiana, through Mississippi Sound, Alabama (Fig. 2). For a subset of these sites $(n=79)$, synoptic data on shoreline erosion was available from companion studies '(non-persistent oil that normally presents as sheens), on the effect of the DWH oil spill on salt marshes (Hester et al. 2016, Willis et al. 2016) that allowed us to evaluate the consequences of changes in oyster cover on a critical ecosystem service-erosion control and facilitation of adjacent vegetated shorelines. Specifically, we tested the hypotheses that percent cover of oyster habitat and oyster abundance would change as a function of shoreline oiling resulting from the 2010 DWH oil spill and that loss of oyster habitat would result in changes in shoreline erosion rates.

\section{MATERIALS AND METHODS}

Oyster habitat adjacent to emergent salt marsh (hereafter referred to as nearshore or intertidal oysters) was surveyed in the north-central GoM (between Terrebonne Bay, Louisiana, and Mississippi Sound, Alabama) to evaluate the condition (distribution and abundance) of nearshore oysters as a function of shoreline oiling or response activities, including releases of fresh water from large river diversion structures in Louisiana, following the DWH oil spill. Sites (200 m long stretches of shoreline) were mapped to estimate oyster cover, as indicated by the presence of shell substrate. Where nearshore oysters were detected, sites were sampled for oyster density (number of oysters $\mathrm{m}^{-2}$ ) and size frequency. Sampling occurred between 14 February and 26 April 2013, i.e. 3 yr post spill.

\section{Site selection}

Oyster sampling locations were selected from a large sampling universe of 2779 sites assessed in 2010 along the coastline of the northern GoM from Rollover Lake, Louisiana, to Apalachee Bay, Florida. Based on repeated observations by response surveys (shoreline cleanup and assessment technique, SCAT) and natural resource damage assessment (NRDA) teams, shorelines along the northern GoM were evaluated and assigned to 1 of 5 shoreline oil exposure classes, each describing a particular pattern of oiling over time (Nixon et al. 2016). For vegetated shorelines, these classes included 'heavy persistent oiling' (where heavy or moderate oiling was repeatedly observed over a period of $\geq 12$ wk between April 2010 and February 2015), 'heavy/moderate oiling' (where moderate or heavy oiling persisted for $<12 \mathrm{wk}$ ), 'lighter oiling' (non-persistent oil that normally presents as sheens), 'no oil observed,' and 'shoreline not surveyed' by linear shoreline evaluation methods. Of these sites, 187 along SCAT-surveyed shorelines were randomly chosen that represented the range of shoreline oiling categories and potential influence of the late spring/early summer freshwater diversion releases in 2010 from Terrebonne Bay, Louisiana, and Mississippi Sound, Alabama (Fig. 2). Many of these 187 sites were also chosen for evaluation under the NRDA-sponsored marsh edge and sandy shoreline study and the coastal vegetation study (www.gulfspillrestoration.noaa.gov/oilspill/gulf-spill-data/). Vegetation along the majority of sites was classified as mainland herbaceous saltmarsh (primarily Spartina alterniflora, S. patens, or Juncus roemerianus), with some sites classified as mixed black mangrove Avicennia germinans and Spartina spp. or Phragmites australis dominated. Additional locations from the original sampling universe were randomly added to represent and balance shoreline oiling categories and add coverage for Mississippi Sound, Breton Sound, or Marsh Island shorelines that could have been affected by freshwater releases. Freshwater diversion structures located in upper Barataria (Davis Pond) and Breton Sound 

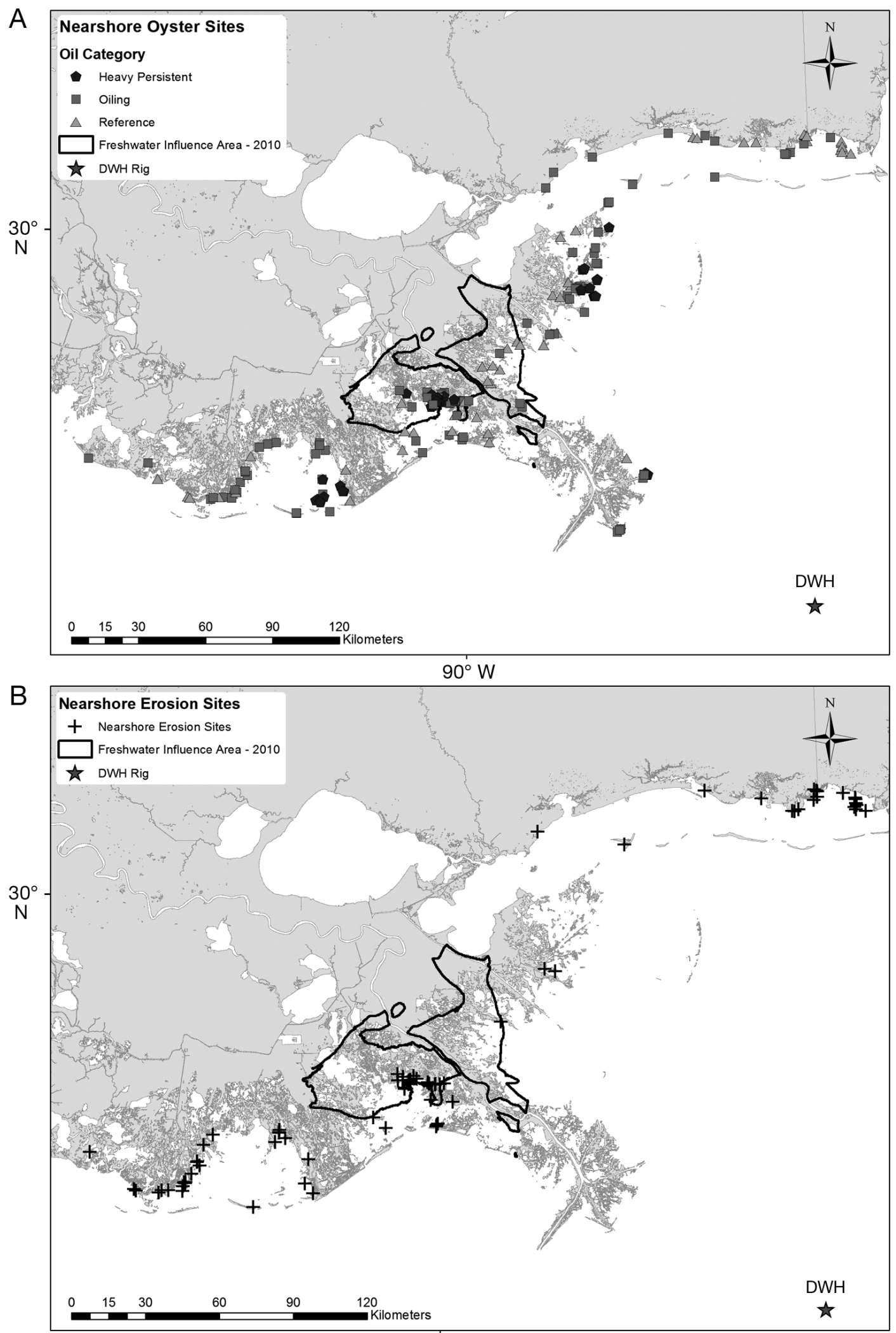

$90^{\circ} \mathrm{W}$

Fig. 2. North-central Gulf of Mexico, showing (A) locations of nearshore oyster sampling locations by oiling category and (B) locations where shoreline erosion rates were documented. DWH: Deepwater Horizon 
(Caernarvon) Estuaries were open from late April through mid-August 2010 as a response action by the State of Louisiana to keep oil out of the estuaries (Martínez et al. 2012, Rose et al. 2014), releasing $212000 \mathrm{l} \mathrm{s}^{-1}$ (Davis Pond) and $226000 \mathrm{l} \mathrm{s}^{-1}$ (Caernarvon) of Mississippi River water directly into those estuaries. Normally these structures are opened only during the cooler winter and early spring months of each year because of potential impacts to oysters and other fisheries from low-salinity water exposure during the warm late-spring and summer months (Turner 2006, Rose et al. 2014). The additional sampling locations were probabilistically selected using the generalized random tessellation stratified sampling procedure (Stevens \& Olsen 1999, 2004). The 187 sites sampled in 2013 represent a range of exposures to both oiling from the DWH spill in 2010 and changes in salinity resulting from actions undertaken by the State of Louisiana in response to the spill. Unsurveyed sites originally assigned to the 'not surveyed' oiling category were excluded from further consideration.

\section{Distribution of nearshore oysters}

Following site selection, 4 field teams mapped oyster shell and other hard substrate over a total of $200 \mathrm{~m}$ of shoreline length at each of 187 sites. Each site was divided into 40 transects ( 20 on each side of a center location that was randomly chosen 0 to $5 \mathrm{~m}$ to the right of site center coordinates). Transects ran perpendicular to the shoreline, were 15 to $20 \mathrm{~m}$ in length (measured from the end of the vegetation line to offshore), and were spaced $5 \mathrm{~m}$ apart. At each sampling site, the transect start location (latitude and longitude) and direction (degrees) were recorded. Field teams cast a Y-shaped metal bar (secured to the end of a fiberglass meter tape) between 15 and $20 \mathrm{~m}$ from shore in a direction perpendicular to the shoreline and then slowly pulled it back along the sea floor, feeling for vibrations through the tape that would indicate the interaction of the bar with oyster shell. Transect lengths were measured beginning at the nearest meter mark on the tape. All field teams were trained in areas with known configurations of oyster shell and soft substrate prior to field work.

Substrate along each of the 40 transects at a site was recorded as either type 1 (soft mud), 2 (moderately firm mud, firm mud or sand, and buried shell), or 3 (exposed shell or reef) for each meter of the transect. Each meter of substrate was assessed either by the feel of the implement on the substrate as the bar was pulled back toward the shore or through a combination of feel and visual observation when oysters were clearly visible. Some segments of the transects could not be mapped because the implement could not be thrown to the full $20 \mathrm{~m}$ extent, because of the presence of a dock or other obstruction, or if the field crew could not safely map the transect, for example, because of the presence of a deep channel extending from the shoreline at the transect start. The proportion of type 3 substrate cover, i.e. the percent cover of oyster habitat, for each mapped nearshore site was estimated as the total length of meters identified as type 3 substrate divided by the total length of meters mapped at that site.

We also examined the potential for response and oil clean-up activities that occurred on the shoreline to affect oyster cover. We reviewed records collected by NOAA related to shoreline oil spill response activities, including documents, database records, maps, and spatial data associated with pre- and post-oiling shoreline response activity operational work orders, and classified each site as receiving onsite response treatment or not treated. Onsite response activities included placement of booms adjacent to shorelines to prevent oil from reaching shorelines; flushing marsh surfaces with water; cutting and raking marsh vegetation; removing wrack and vegetation; raking heavy oil deposits from soil surfaces; and placing loose sorbent material (Zengel et al. 2015). We did not attempt to separate treated areas by severity of disturbance because all onsite response activities would be associated with physical alteration of the soft-sediment habitat seaward of the marsh, and most onsite response activities would involve landing boats on the marsh edge and deploying crews at the sites.

\section{Oyster abundance}

Site mapping determined segments where oyster shell was found and therefore could be surveyed for abundance of oysters using quadrat sampling. Segments were defined as linear segments of exposed shell at least $1 \mathrm{~m}$ in length. Oyster abundance was sampled at up to 6 randomly selected quadrats per site. Quadrat sample locations were chosen from among segments where oyster shell was found using a 2-step process. First, each segment of exposed shell identified during mapping was numbered. Because segments could be multiple meters in length, field teams used a random number table to select $1 \mathrm{~m}$ long sections of segments for quadrat sampling. Up to 6 
independent segments of exposed shell were sampled, depending on the number of segments identified and the length of available segments. In a given segment, each selected $1 \mathrm{~m}$ long section of shell was only sampled once. Quadrats of $1 \mathrm{~m}^{2}$ were made of PVC. All substrate encompassed within the quadrat was collected by hand up to a depth of approximately $4 \mathrm{~cm}$ and placed in a labeled burlap sack. Samples were transported on ice to the Dauphin Island Sea Lab, Alabama. Within 48 to $72 \mathrm{~h}$ of collection, live oysters from each sample were enumerated in 3 size classes: market $(\geq 75 \mathrm{~mm})$, seed $(25-74.9 \mathrm{~mm})$, and spat ( $<25 \mathrm{~mm}$ ). Water quality measurements (salinity, temperature, dissolved oxygen) were also taken on the day of sample collection (recorded at the site center point at a water depth of at least $20 \mathrm{~cm}$ ).

\section{Historical salinity}

We examined the salinity history at each of our sites to determine whether average salinity differed by our design and could possibly confound our analyses. We utilized the network of salinity monitoring sites (both continuous sampling instruments as well as discrete samples publicly available) to determine if salinity varied by the 3 shoreline oiling categories and whether the sites were influenced by the 2 freshwater diversion areas. Salinity records were synthesized from several sources to complete the analysis: Louisiana Department of Wildlife and Fisheries, Louisiana Coastal Protection and Restoration Authority, Louisiana Department of Health and Hospitals, Louisiana Department of Environmental Quality, Mississippi Department of Environmental Quality, and US Geological Survey (complete details of the synthesis are given in Powers et al. 2017, this Theme Section).

\section{Erosion/shoreline change}

Prior to sampling nearshore oysters, several other NRDA studies were undertaken to evaluate exposure and injury to nearshore flora and fauna. Seventynine nearshore oyster sampling stations were colocated with sites included in an evaluation of coastal wetland vegetation that collected synoptic data on shoreline erosion. The coastal wetland vegetation assessment (CWV) was intended to evaluate the effects of plant stem oiling on plant productivity, cover, and health and shoreline change. CWV sites were classified by degree of oiling on plant stems and by vegetation type. At each site, a transect was established with 1 to 3 fixed-location, permanent plot pairs (for observations and destructive sampling). The length of the initial transect was determined by the length of oil penetration into the vegetation, as observed during the pre-assessment survey conducted in the summer of 2010, with a maximum length of $30 \mathrm{~m}$ from the intersection of water and vegetation. For reference sites, at which no oil was observed, the default transect length was $20 \mathrm{~m}$. The number of vegetation sampling plots (up to 3 ) and the location of the plots along the transect were determined by transect length. The permanent location of the most shoreward plot pair was established with the shore edge of the plots located $1 \mathrm{~m}$ from the marsh edge at the time of the first sampling event.

In addition to the plant metrics collected at each plot, observations and measurements of shoreline change were made during each CWV sampling event. The length of the transect was first recorded when sites were established in the fall of 2010 (Louisiana sites) or the spring of 2011 (Mississippi and Alabama sites). At each subsequent survey (Spring 2011, Fall 2011, Fall 2012, Fall 2013), the distance from the inland stake to the marsh edge was measured, and observations of erosion or shoreline change were recorded. GPS coordinates were obtained from the shoreline and inland ends of the transect as well as the lower left corner of each plot (facing inland, the left-hand shoreward corner). Coordinates were generally obtained once per site with a GPS device with sub-meter accuracy (e.g. Trimble GeoXH), typically the first time a site was sampled. Each subsequent time a site was visited, a GPS device such as the Garmin GPSMAP 76 or the Garmin GPSMAP 60 was used (with an estimated accuracy of $3 \mathrm{~m})$. The 79 oyster sites that are co-located with the coastal vegetation sites are used here to evaluate relationships between oyster cover and shoreline change from the fall of 2010 to the fall of 2013.

\section{Wind/wave energy}

To examine other factors that could influence oyster cover and shoreline change, an exceedance wind frequency-based exposure index $\left(E I_{e}\right)$ was calculated and applied to sample stations. The index estimates exposure to extreme wind-driven wave energy based on fetch (in this work, the fetch at any given location on the shoreline is defined as the maximum overwater distance in a given direction from that point) and the proportion of all winds that exceed a specific 
velocity in each evaluated direction. The index method was based on Keddy (1982) with modifications. The $E I_{e}$ used in this analysis is based on critical wind speed exceedances using 2010-2013 data from 4 NOAA National Data Buoy Center stations between Lake Calcasieu, Louisiana, and Apalachicola Bay, Florida, resulting in a range of index values from 4 to 7593 for 187 investigated sites. Index values are computed for each year between 2010 and 2013 from overwater modified effective fetch values $\left(f_{i}\right)$, percent of wind speed observations exceeding a threshold using 8 directional bins, interpolated from 4 station data according to the following equation:

$$
E I_{e}=\sum_{i=1}^{8} e_{\mathrm{i}} \times f_{i}
$$

where $i$ is 1 of 8 cardinal directional headings representing $45^{\circ}$ intervals, $e_{i}$ is the fractional proportion of time the wind was observed from the $i^{\text {th }}$ direction at greater than the overall $20 \%$ exceedance value for all wind speed observations at that station in the given year, and $f_{i}$ is the open water fetch in meters from the $i^{\text {th }}$ direction. These indices were calculated for each of the 4 stations. After generating the index using metrics for each station, the 4 resultant wind rasters were averaged together at the location of each site using a weighting scheme based on the squared inverse distance from each respective station to derive a year-specific $E I_{e}$ estimate. The overall 2010-2013 EI $I_{e}$ used in the analysis is then calculated as the sum of the 4 computed annual $E I_{e}$ indices.

\section{Data analysis}

The sampling design for the analysis of percent cover of oyster habitat represents a $3 \times 2$ factorial ANOVA evaluating 3 shoreline oiling categories and 2 freshwater conditions (inside or outside a polygon of freshwater influence) (Table 1). Freshwater influence polygons were drawn based on examination of the duration and timing of freshwater releases in 2010 compared to typical and historical freshwater

Table 1. Distribution of sampling sites by shoreline oiling and freshwater (FW) diversion treatment category. Numbers in parentheses indicate sites where onsite response activities occurred

\begin{tabular}{|c|c|c|c|c|}
\hline \multirow[t]{2}{*}{ FW influence } & \multirow{2}{*}{ Reference } & \multicolumn{2}{|c|}{ _ Shoreline oiling —ـ } & \multirow[t]{2}{*}{ Total } \\
\hline & & Oiled & Heavy persistent & \\
\hline Outside polygon of FW influence & e $34(0)$ & $63(34)$ & $24(22)$ & 121 \\
\hline Inside polygon of FW influence & $20(0)$ & $31(11)$ & $15(12)$ & 66 \\
\hline Total & 54 & 94 & 39 & 187 \\
\hline
\end{tabular}

flows (Fig. 2). For the purposes of evaluating nearshore oysters, we reduced the 5 shoreline oiling categories to 3: heavy persistent oiling as defined above, oiled, and no oil observed. The heavy/moderate and lighter oiling categories were combined into an 'oiled' category to distinguish effects of heavy persistent oiling, such as heavy fouling and smothering, from those sites that experienced more subtle effects of oiling (e.g. less physical fouling). Dependent variables in the analyses included percent cover of nearshore oyster habitat and density of market-, seed-, and spat-sized oysters per site. For each site, the abundance of oysters by size categories was averaged for the analyses using up to 6 replicate quadrats. Sites with and without any oyster cover were included in the analysis of percent cover, whereas only sites where quadrats were collected (positive percent cover) were used in the analyses of abundance.

The effect of onsite shoreline response/oil cleanup activities on percent cover of oyster habitat was tested using an unpaired, 2-tailed $t$-test assuming unequal variances. Treated sites were compared to untreated sites in the heavy persistent and oiling categories (as no response activities occurred in the no oil observed sites). We pooled treated and untreated sites across the 2 oiling categories to provide sufficient replication for the test. Although the potential for an interaction between treatment and oiling category exists, the lack of response activities in any of the no oil observed sites prevents resolving any interaction. Because of the potential bias of including all untreated sites from the no oil observed areas, which had higher percent cover than the other oiling categories, we excluded all no oil observed sites from this analysis.

To determine if the presence of oyster cover affected the erosion rate of adjacent vegetated marsh, we performed a series of univariate analyses. First, we tested whether the presence/absence of oyster habitat as measured in the winter of 2013 is associated with lower shoreline erosion from the fall of 2010 to the fall of 2013 using an unpaired, 1-tailed $t$-test assuming unequal variance. Next, we examined site-specific values of $E I_{e}$ scores to evaluate the possibility that areas with higher erosion potential had a higher probability of not having oyster cover. To determine whether erosion potential $E I_{e}$ score differed between areas with and without oyster cover, we 
performed a 2-tailed $t$-test analyzing whether the sum of annual site $E I_{e}$ values from 2010-2013 differed in areas where oysters were present versus absent. Presence was defined as sites with $\geq 0.5 \%$ cover of oyster habitat. All analyses were performed in JMP version 11 (SAS Institute) on untransformed data. Mean values are given \pm SE.

\section{RESULTS}

\section{Distribution of oyster habitat}

Percent cover of oyster habitat varied as a function of both shoreline oil exposure and location of sampling within the freshwater diversion release polygons. The interaction between the 2 factors was not significant (Table 2). Lowest percent cover values were recorded in areas adjacent to marshes that experienced heavy and persistent oiling $(2.3 \pm 0.7 \%)$, followed by areas that experienced more moderate and less persistent oiling $(6.9 \pm 1.3 \%)$ and reference shorelines where no oil was observed $(10.3 \pm 2.1 \%$; Fig. 3). The proportion of sites with no oysters, i.e. sites with percent cover of oyster habitat $<0.5 \%$, was also highest adjacent to marshes that experienced heavy persistent oiling (56\%), followed by oiling ( $43 \%$ ) and no oil observed ( $24 \%)$. Sampling locations within the freshwater diversion-affected areas had higher percent cover of oyster habitat than areas outside $(9.6 \pm 2.0 \%$ vs. $5.4 \pm 0.8 \%)$. Onsite response activities affected percent cover of oyster habitat. For oiled sites with documented onsite response activities, percent cover was significantly lower than oiled areas that did not have cleanup or response activities $(t$-test assuming unequal variances, $t=-3.20, \mathrm{df}=$ 179, $\mathrm{p}=0.002,2$-tailed). The mean oyster percent cover at treated sites was $3.8 \%$ compared to $7.9 \%$ at untreated sites (Fig. 4).

Live oysters were found at virtually all sites that had oyster habitat. In most cases, abundance of oysters did not vary significantly by shoreline oiling category, sampling location relative to a freshwater diversion polygon, or their interaction (Table 2). The interaction between the 2 factors, i.e. shoreline oiling and freshwater diversion polygon, was not significant in any of the ANOVAs. Abundance of spat-, seed-, or marketsized oysters in areas where oyster habitat was present did not differ significantly with oiling, although a trend of lower abundances for spat- and seed-sized oysters was noticeable in the heavy persistent oiling category (Table 2, Fig. 5). The only exception was the abundance of market-sized oysters, which was significantly higher in locations that were within the freshwater diversion polygon ( $4.7 \pm 1.5$ vs. $2.5 \pm 0.8$ oyster $\mathrm{m}^{-2}$ ).

The historical salinity pattern revealed a consistent difference between sites within and outside the freshwater diversion influence area but not among shoreline oiling category within those zones (Fig. 6). Salinity for reference, oiled and heavy persistent oiled sites ranged from 7-18 ppt inside the area influenced by the freshwater diversion openings and 18-24 ppt in the area outside the freshwater diversion.

Table 2. Summary of 2-way ANOVAs testing the effects of shoreline oiling category and potential exposure to freshwater diversion in May to August 2010 on oyster cover and oyster density metrics measured in February 2013. Significant effects $(\mathrm{p}<0.05)$ are presented in bold

\begin{tabular}{|c|c|c|c|c|c|c|}
\hline Response & Sample size & Source & df & SS & $F$ & $\mathrm{p}$ \\
\hline \multirow[t]{4}{*}{ Oyster habitat (\% cover) } & \multirow[t]{4}{*}{187} & Shoreline oiling category & 2 & 0.18 & 6.24 & 0.002 \\
\hline & & Freshwater diversion exposure & 1 & 0.07 & 4.74 & 0.031 \\
\hline & & Interaction & 2 & 0.06 & 1.95 & 0.145 \\
\hline & & Error & 181 & 2.60 & & \\
\hline \multirow[t]{4}{*}{ Market-sized oysters (no. $\mathrm{m}^{-2}$ ) } & \multirow[t]{4}{*}{119} & Shoreline oiling category & 2 & 2.46 & 0.03 & 0.976 \\
\hline & & Freshwater diversion exposure & 1 & 238.20 & 4.76 & 0.031 \\
\hline & & Interaction & 2 & 203.59 & 2.03 & 0.136 \\
\hline & & Error & 113 & 5654.96 & & \\
\hline \multirow[t]{4}{*}{ Seed-sized oysters (no. $\mathrm{m}^{-2}$ ) } & \multirow[t]{4}{*}{119} & Shoreline oiling category & 2 & 3114.65 & 1.27 & 0.285 \\
\hline & & Freshwater diversion exposure & 1 & 1914.91 & 1.56 & 0.214 \\
\hline & & Interaction & 2 & 1319.62 & 0.54 & 0.586 \\
\hline & & Error & 113 & 138791.06 & & \\
\hline \multirow[t]{4}{*}{ Spat-sized oysters (no. $\mathrm{m}^{-2}$ ) } & \multirow[t]{4}{*}{119} & Shoreline oiling category & 2 & 274.79 & 1.10 & 0.338 \\
\hline & & Freshwater diversion exposure & 1 & 24.01 & 0.19 & 0.663 \\
\hline & & Interaction & 2 & 14.04 & 0.06 & 0.946 \\
\hline & & Error & 113 & 14180.49 & & \\
\hline
\end{tabular}




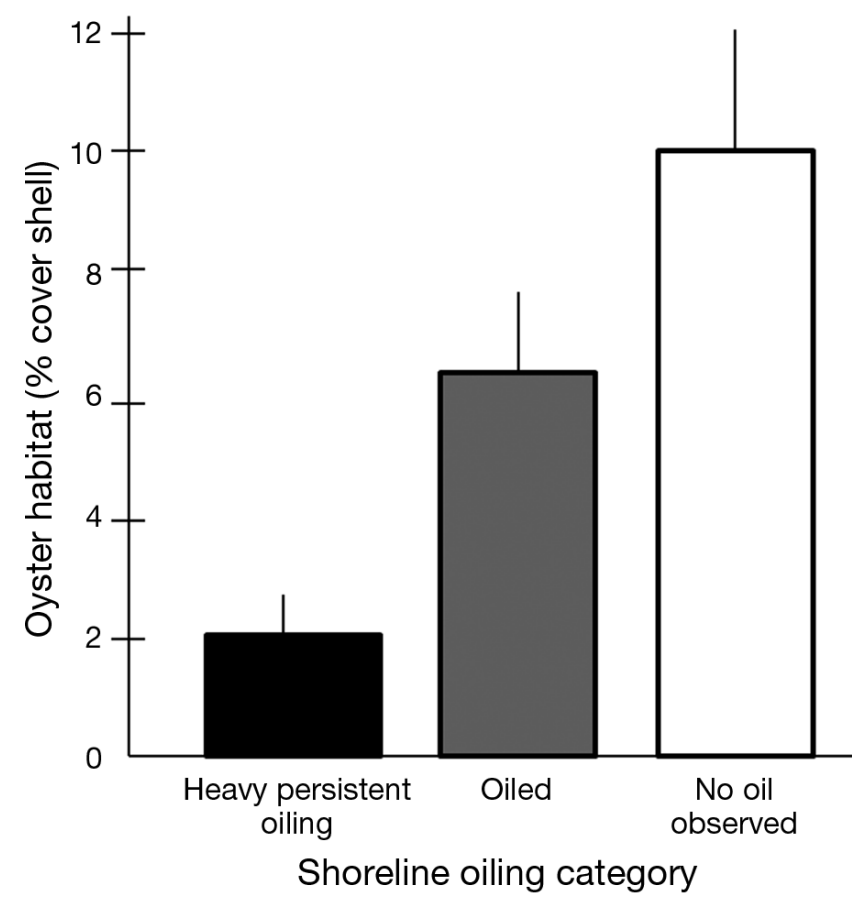

Fig. 3. Mean $( \pm \mathrm{SE})$ percent of oyster habitat found adjacent to vegetated shorelines with heavy persistent, moderate (oiled), and no oiling from Terrebonne Bay, Louisiana, to Mississippi Sound, Alabama

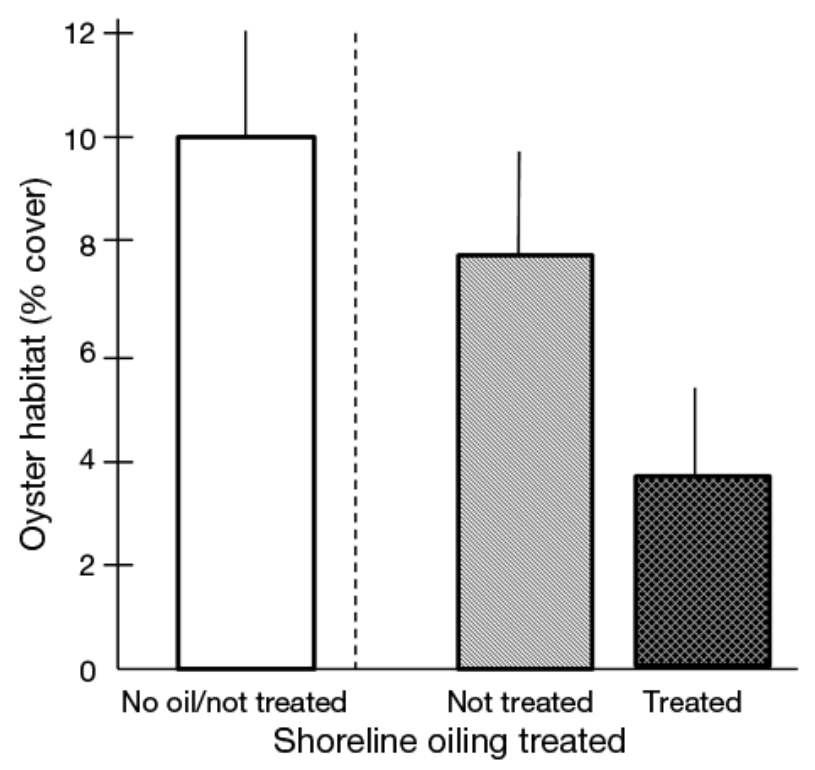

Fig. 4. Mean $( \pm \mathrm{SE})$ percent cover of oyster habitat in heavy persistent oiling and oiled areas subject to response and clean-up activities (Treated) and where no treatment occurred (Not treated). Means are significantly different at $p<0.05$. Mean percent cover for untreated/no oil observed sites (white bar) is shown for reference only and was not included in the statistical analysis

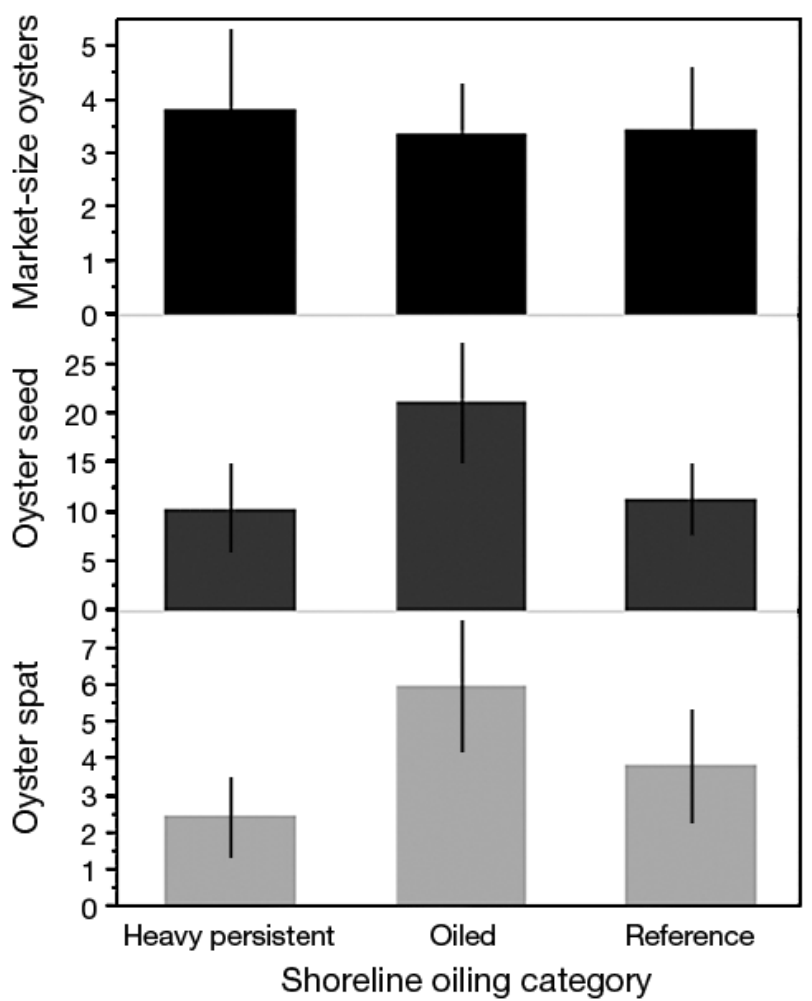

Fig. 5. Mean $\left( \pm \mathrm{SE}\right.$ ) density (oysters $\mathrm{m}^{-2}$ ) by shoreline oiling exposure category measured in Winter 2013 at 187 sites from Terrebonne Bay, Louisiana, to Mississippi Sound,

Alabama, for market-, seed-, and spat-sized oysters

\section{Erosion and percent cover}

Erosion of marsh occurred at almost all of the 79 sites where oyster metrics and shoreline change (transect lengths) were measured. The presence of oyster habitat was associated with significantly reduced shoreline erosion in the adjacent marsh ( $t$-test assuming unequal variances, $t=-1.83, \mathrm{df}=27$, $\mathrm{p}=0.0396,1$-tailed). Where oyster cover was absent, erosion was $8.4 \pm 2.5 \mathrm{~m}$ over the $3 \mathrm{yr}$ period. In contrast, erosion rate where oyster habitat was present was $3.8 \pm 0.6 \mathrm{~m}$ over the same period. While oyster presence/absence significantly affected marsh erosion, onsite response activity along the shoreline did not have a significant effect on erosion rate $(p=0.152$ for $t$-test) although a trend of higher erosion at sites with onsite response activities was noted (mean erosion $7.2 \pm 1.6$ at treated sites vs. $4.6 \pm 1.5 \mathrm{~m}$ over the study period). Linear correlations between percent cover and erosion over the $3 \mathrm{yr}$ window failed to produce a significant relationship ( $p=0.693)$; however, higher rates of erosion were generally associated with lower percent cover. Finally, $E I_{e}$ scores did 


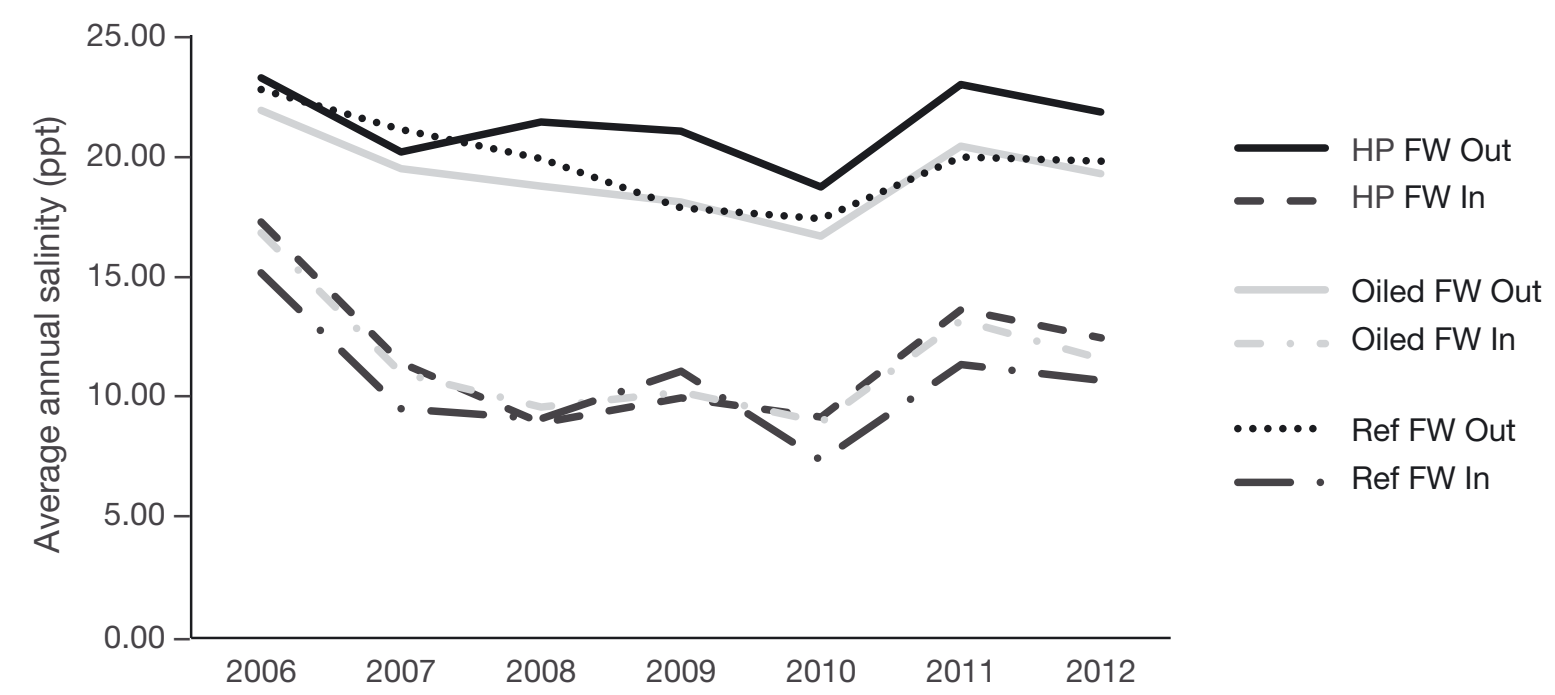

Fig. 6. Average annual salinity (ppt) of oyster sampling sites by shoreline oiling category (heavy persistent [HP], oiled, reference [Ref]) and freshwater diversion exposure (FW In, FW Out: inside, outside of freshwater diversion influence area) from 2006 to 2012

not differ in areas with and without oyster habitat $(\mathrm{p}=0.820)$. Oyster habitat occurred over the full range of $E I_{e}$ scores with mean values similar between areas with (5072 \pm 595$)$ and without oyster habitat $(5280 \pm 704)$.

\section{DISCUSSION}

The prevalence of biogenic habitat in nearshore areas of the world is a key factor that explains the high productivity of these areas. Biogenic habitats are hotspots of primary and secondary productivity within the coastal landscape by providing refuge and food for juvenile fish and invertebrates and enhanced nutrient cycling, among other ecosystem services (Heck et al. 2003). In the GoM, the most common habitat encountered in estuarine and coastal areas is salt marsh (Minello et al. 2003). The frequent inundation of marshes, driven primarily by wind in this microtidal environment, provides access to food and shelter for marine animals and accounts for a large secondary production of invertebrates (Rozas 1995, Minello et al. 2003, Haas et al. 2004). Oyster reefs and seagrass meadows, while less common, also provide shelter and food for fish and invertebrates (Heck et al. 2003, Coen et al. 2007, Grabowski \& Peterson 2007). Often these habitats occur adjacent to one another and form a complex mosaic of structural refuge and foraging habitat for fish and invertebrates as well as terrestrial and avian vertebrates (Grabowski et al. 2005). One of the most common couplings along the US Atlantic and Gulf Coast is that of saltmarsh and fringing oyster habitat (Grabowski et al. 2005, Geraldi et al. 2009). Our estimate that $76 \%$ of salt marsh habitat in the no oil observed areas had adjacent oyster cover shows that such pairing frequently occurs in the northern GoM. The average percent cover of oysters in the no oil observed was $10 \%$, which indicates that this landscape feature is sufficiently abundant to be important for ecosystem processes in the area (e.g. fish utilization and nutrient cycling). Baseline information on fringing oyster habitat is largely absent from the published literature, thus our estimate that the habitat is ubiquitous (76\% of unimpacted sites) and relatively abundant within sites (10\% cover) establishes a new baseline to examine the importance of this habitat coupling in coastal ecosystems.

As with other oil spills, oil transported in surface waters following the explosion and blowout of the DWH well was deposited in vast quantities along vegetated and non-vegetated shorelines. While oiling and recovery of salt marshes has received substantive attention in previous oil spills, no published studies exist on the fate of nearshore oyster habitat following an oil spill. Reduction in the amount of oyster habitat was evident in areas that were classified as having experienced shoreline oiling compared to areas where no oil was observed. For shorelines that were characterized as heavily and persistently oiled, shell habitat that would support oysters was on average only $2 \%$ compared to over $10 \%$ in non-oiled areas. In our study that surveyed an area of roughly $4000 \mathrm{~m}^{2}$ (200 m shoreline length $\times 20 \mathrm{~m}$ width), this change in percent cover is equivalent to losing approximately $320 \mathrm{~m}^{2}$ of oyster habitat at each of those sites characterized as heavy persistent oiling and 
approximately $135 \mathrm{~m}^{2}$ in areas characterized as oiled. Oyster habitat appeared similar among sites where it was detected, with live oyster in all 3 oyster size classes present at comparable densities across the oiling treatments. The 2 patterns (percent cover decline while remaining reef had similar density) suggest that the injury resulting from the DWH oil spill in summer of 2010 was largely a function of an acute disturbance that occurred during or within 1 yr after the oil spill (assuming approximately 2 yr for oyster growth from spat to market size; see growth function in Soniat et al. 2012).

The pattern of reduced oyster cover could be a function of extensive oiling and smothering of oysters along the shoreline during the spill as well as disturbance from shoreline cleanup and onsite response activities that occurred in oiled areas. The latter is supported by the pattern of reduced percent cover of oyster habitat in areas where response activities occurred. Deployment of field crews, landing of vessels, booms scouring the shallow bottom sediments, flushing of oil-soaked contaminated marshes with water all could result in trampling, smothering, and burial of oyster habitat. The difference between untreated and treated shorelines does not preclude that direct oiling of oyster habitat also contributed to the loss of oyster cover. Oysters that occur near the marsh edge often inhabit very muddy, soft sediments, and their position above the sediment surface is a precarious one because the weight of the oyster itself would be expected to cause sinking over time. The filtration activity of the oysters and the annual recruitment of new oysters that gregariously settle on oyster shell may thwart burial and promote vertical relief. Because most of the shell habitat has a vertical relief of no more than $50 \mathrm{~cm}$ (S. Powers pers. obs.), smothering by the mousse-like oil residue that coated many shorelines (Fig. 1) following the oil spill could have prevented filtration and additional recruitment. Over a relatively short time this degraded oyster habitat could have been buried.

Regardless of the injury pathway (shoreline oil spill response activities or direct oiling of shorelines), oyster habitat in areas receiving oil following the DWH oil spill was severely degraded. Given the documented decreases in oyster habitat over recent decades in the GoM (see zu Ermgassen et al. 2012), such episodic losses are a reason for added concern and could further stress a habitat near its tipping point. Because the fishery value of nearshore oysters in the northern GoM is limited (although these areas have the potential to serve as a de facto spawning sanctuary that 'seeds' areas of harvest), the loss of ecosystem functions and services is the pressing concern for resource managers. Extensive literature now exists on the ecological benefits of oyster reefs (see Coen et al. 2007, Grabowski et al. 2012 for recent reviews) and supports that the loss of habitat can have effects on nutrient cycling (Piehler \& Smyth 2011, Beseres Pollack et al. 2013, Kellogg et al. 2013), fish and invertebrate production (Peterson et al. 2003), water clarity (Newell \& Koch 2004, Grizzle et al. 2008), and shoreline stabilization (Scyphers et al. 2011). Collectively, the annual economic value of these services (excluding oyster harvest) was recently estimated to total US \$5500-99000 ha ${ }^{-1}$ (Grabowski et al. 2012). We were able to test the potential for one of these ecosystem services, viz. shoreline stabilization, within our study area by coupling our measurements of oyster habitat with measurements of shoreline erosion collected under companion studies (Hester et al. 2016, Willis et al. 2016).

The presence of oysters along the shoreline reduced the 3 yr erosion rate by over $50 \%$. Our analysis of $E I_{e}$ scores also provides strong evidence that the pattern is not a function of oyster preference or physical disturbance in areas that experience more erosive forces. Oyster cover occurred across a spectrum of erosive conditions as measured by $E I_{e}$ scores, thus oyster cover is not restricted to only low energy sites where erosion would be expected to be reduced. Consistent through all of our findings is the role of oyster habitat reducing erosion. Although shoreline stabilization has been increasingly cited as a potential benefit of oyster reefs, few empirical studies exist that quantify the benefit (NRC 2014, Powers \& Boyer 2014). Our study is the first to provide field-collected data over a large geographic area that establishes that the presence of oyster reefs mitigates or buffers erosion. Previous studies (e.g. Piazza et al. 2005, Scyphers et al. 2011) were performed at sites spanning just a few 100s of m. Piazza et al. (2005) demonstrated that spreading low-relief oyster shell cultch could reduce shoreline retreat in areas of low to moderate erosive energies in Sister Lake, Louisiana. Scyphers et al. (2011) demonstrated that erosion and vegetation retreat was reduced behind restored oyster reefs near Point aux Pins, Alabama. Interestingly, both studies demonstrated effects of similar magnitude: $40 \%$ reduction in Scyphers et al. (2011) and $25 \%$ in Piazza et al. (2005). Emergent oyster habitat protects shorelines by dampening wave energies and potentially trapping sediments eroded from the shoreline or transported through nearshore currents (NRC 2014). The lack of a strong correlation between 
percent cover and erosion (our finding is based on presence/absence) demonstrates the complexity of the relationship. Our percent cover estimate is based on site-level measurements over an area of $4000 \mathrm{~m}^{2}$ extending $20 \mathrm{~m}$ from the shoreline. Sites varied in their distribution of oyster habitat, but in general, oyster cover was greatest closer to the shoreline (peaking around 2-3 $\mathrm{m}$ from the marsh edge). The local arrangement of oyster patches likely influences the wave attenuation properties of oyster habitat (Lunt et al. 2017), and this unexplained variance could contribute to the lack of a strong fit in the relationship between oyster density and erosion (Koch et al. 2009).

Our results demonstrate that nearshore marsh ecosystems were degraded through both direct (loss of oyster habitat) and indirect (erosion of marsh from loss of oyster habitat) pathways as a consequence of the DWH oil spill. Reduction in oyster habitat occurred as a direct result of shoreline oiling or onsite response and oil cleanup activities. This reduction leads to increased marsh erosion rates. While indirect effects of oil spills have been documented (see Peterson et al. 2003), the disruption of the strong facilitation between 2 ecosystem engineers represents a previously undocumented pathway of injury resulting from an oil spill. Unfortunately, additional monitoring necessary to document recovery time was not conducted due to cost considerations; however, natural recovery times would be expected to take decades given modest natural spreading. Rodriguez et al. (2014) reported natural spreading rates of $10-30 \mathrm{~cm} \mathrm{yr}^{-1}$ of radial expansion for restored oyster reefs in North Carolina with high vertical relief and shell material, but extremely low $(<5 \mathrm{~cm})$ on patches without adequate hard substrate for oysters to recruit. The latter reef types are more similar to those measured in our study. Consequently, the lost expanses of oyster habitat along GoM shorelines will persist until intervention (shell placement as part of a restoration program) is initiated. This lingering effect would be expected to result in further loss of vegetated marsh and exacerbate declines in ecosystem function. Given the current high rate of wetland loss in the northern GoM (Kennish 2001), particularly in Louisiana where much of our study was conducted, and the decades-long, slow demise of oyster reefs in the GoM (zu Ermgassen et al. 2012), the additional loss of both habitats resulting from the DWH oil spill represents a conservation emergency that requires rapid restoration of this habitat mosaic.

The findings of this study, based on co-located coastal wetland vegetation study sites and oyster study sites, do not preclude other findings of relationships among shoreline vegetation, erosion, and/or oil exposure based on further analysis of data from the universe of the nearshore sites studied as part of the DWH NRDA. Moreover, the loss of vegetated shoreline as a result of oyster habitat degradation does not preclude other direct and indirect effects resulting from the oiling of vegetated areas, which our study had limited statistical power to test. Instead, this study documents an entirely unreported pathway of injury from oil to greater potential marsh erosion.

Acknowledgements. This paper relied on data collected as part of investigations being conducted cooperatively among the National Oceanic and Atmospheric Administration (NOAA), other federal and state natural resource agencies, and BP as part of the DWH NRDA. The opinions in the paper are those of the authors and not necessarily of all participants in the cooperative studies upon which the paper is based. We thank the members of the field crews who spent long, cold winter days in the marshes of the GoM. We also thank Claire Pabody and many others in the Fisheries Ecology Lab at the Dauphin Island Sea Lab for assistance in processing the lab samples. Michelle Baroussa Stahl, Lyman McDonald, Shay Howlin, and Fawn Hornsby of West, Inc. provided valuable guidance during the planning and quality assurance/quality control review of the data. Finally, we thank Jessica Murray for her comments and assistance on the manuscript.

\section{LITERATURE CITED}

Beck MW, Heck KL Jr, Able KW, Childers DL and others (2001) The identification, conservation, and management of estuarine and marine nurseries for fish and invertebrates. Bioscience 51:633-641

* Beseres Pollack J, Yoskowitz D, Montagna PA (2013) Role and value of nitrogen regulation provided by oysters (Crassostrea virginica) in the Mission-Aransas Estuary, Texas, USA. PLOS ONE 8:e65314

Bologna PAX, Heck KL (2002) Impact of habitat edges on density and secondary production of seagrass-associated fauna. Estuaries 25:1033-1044

* Bruno JF, Stachowicz JJ, Bertness MD (2003) Inclusion of facilitation into ecological theory. Trends Ecol Evol 18: 119-125

Coen LD, Brumbaugh RD, Bushek D, Grizzle R and others (2007) Ecosystem services related to oyster restoration. Mar Ecol Prog Ser 341:303-307

Costanza R, d'Arge R, de Groot R, Farber S and others (1997) The value of the world's ecosystem services and natural capital. Nature 387:253-261

Costanza R, de Groot R, Sutton P, van der Ploeg S and others (2014) Changes in the global value of ecosystem services. Glob Environ Change 26:152-158

* Dame RF, Patten BC (1981) Analysis of energy flows in an intertidal oyster reef. Mar Ecol Prog Ser 5:115-124

* Driskell WB, Ruesink JL, Lees DC, Houghton JP, Lindstrom SC (2001) Long term signal of disturbance: Fucus gardneri after the Exxon Valdez oil spill. Ecol Appl 11:815-827 
Dyer CL, Leard RL (1994) Folk management in the oyster fishery of the U.S. Gulf of Mexico. In: Dyer CL, McGoodwin JR (eds) Folk management in the world's fisheries: lessons for modern fisheries management. University Press of Colorado, Niwot, CO, p 55-89

Geraldi NR, Powers SP, Heck KL, Cebrian J (2009) Can habitat restoration be redundant? Response of mobile fishes and crustaceans to oyster reef restoration in marsh tidal creeks. Mar Ecol Prog Ser 389:171-180

Grabowski JH, Peterson CH (2007) Restoring oyster reefs to recover ecosystem services. In: Cuddington $\mathrm{K}$, Byers JE, Wilson WG, Hastings A (eds) Ecosystem engineers: concepts, theory and applications. Elsevier-Academic Press, Amsterdam, p 281-298

* Grabowski JH, Hughes AR, Kimbro DL, Dolan MA (2005) How habitat setting influences restored oyster reef communities. Ecology 86:1926-1935

* Grabowski JH, Brumbaugh RD, Conrad R, Keeler AG and others (2012) Economic valuation of ecosystem services provide by oyster reefs. Bioscience 62:900-909

Grizzle R, Greene JK, Coen LD (2008) Seston removal by natural and constructed intertidal eastern oyster (Crassostrea virginica) reefs: a comparison with previous laboratory studies, and the value of in situ methods. Estuaries Coasts 31:1208-1220

Gundlach ER, McCain JC, Fadlallah Y (1993) Distribution of oil along the Saudi Arabian coastline (May/June 1991) as a result of the Gulf War oil spills. Mar Pollut Bull 27:93-96

Haas HL, Rose KA, Fry B, Minello TJ, Rozas LP (2004) Brown shrimp on the edge: linking habitat to survival using an individual-based simulation model. Ecol Appl 14:1232-1247

Halpern BS, Selkoe K, Micheli F, Kappel CV (2007) Evaluating and ranking the vulnerability of global marine ecosystems to anthropogenic threats. Conserv Biol 21: 1301-1315

*Heck KL Jr, Hays G, Orth RJ (2003) Critical evaluation of the nursery role hypothesis for seagrass meadows. Mar Ecol Prog Ser 253:123-136

*Hester MW, Willis JM, Rouhani S, Steinhoff MA, Baker MC (2016) Impacts of the Deepwater Horizon oil spill on the salt marsh vegetation of Louisiana. Environ Pollut 216: 361-370

Keddy PA (1982) Quantifying within-lake gradients of wave energy: interrelationships of wave energy, substrate particle size and shoreline plants in Axe Lake, Ontario. Aquat Bot 14:41-58

Kellogg ML, Cornwell JC, Owens MS, Paynter KT (2013) Denitrification and nutrient assimilation on a restored oyster reef. Mar Ecol Prog Ser 480:1-19

Kennish MJ (2001) Coastal salt marsh systems in the US: a review of anthropogenic impacts. J Coast Res 17: 731-748

Koch EW, Barbier EB, Silliman BR, Reed DJ and others (2009) Non-linearity in ecosystem services: temporal and spatial variability in coastal protection. Front Ecol Environ 7:29-37

Lotze HK, Lenihan HS, Bourque BJ, Bradbury RH and others (2006) Depletion, degradation, and recovery potential of estuaries and coastal seas. Science 312:1806-1809

Lunt J, Reustle J, Smee DL (2017) Wave energy and flow reduce the abundance and size of benthic species on oyster reefs. Mar Ecol Prog Ser 569:25-36

Martínez ML, Feagin RA, Yeager KM, Day J and others (2012) Artificial modifications of the coast in response to the Deepwater Horizon oil spill: quick solutions or longterm liabilities? Front Ecol Environ 10:44-49

Meyer DL, Townsend EC (2000) Faunal utilization of created intertidal eastern oyster (Crassostrea virginica) reefs in the southeastern United States. Estuaries 23:34-45

Meyer DL, Townsend EC, Thayer GW (1997) Stabilization and erosion control value of oyster cultch for intertidal marsh. Restor Ecol 5:93-99

* Minello TJ, Able KW, Weinstein MP, Hays CG (2003) Salt marshes as nurseries for nekton: testing hypotheses on density, growth and survival through meta-analysis. Mar Ecol Prog Ser 246:39-59

Newell RIE, Koch EW (2004) Modeling seagrass density and distribution in response to changes to turbidity stemming from bivalve filtration and seagrass sediment stabilization. Estuaries 27:793-806

*Newell RIE, Cornwell JC, Owens MS (2002) Influence of simulated bivalve biodeposition and microphytobenthos on sediment nitrogen dynamics: a laboratory study. Limnol Oceanogr 47:1367-1379

Nixon Z, Zengel S, Baker M, Steinhoff M, Fricano G, Rouhani S, Michel J (2016) Shoreline oiling from the Deepwater Horizon oil spill. Mar Pollut Bull 107:170-178

NRC (National Research Council) (2003) Oil in the sea III: inputs, fates, and effects. National Academy Press, Washington, DC

NRC (2014) Reducing coastal risk on the east and Gulf Coasts. National Academy Press, Washington, DC

* Peterson CH, Rice SD, Short JW, Esler D, Bodkin JL, Ballachey BE, Irons DB (2003) Long-term ecosystem response to the Exxon Valdez oil spill. Science 302: 2082-2086

* Piazza BP, Banks PD, La Peyre MK (2005) The potential for created oyster shell reefs as a sustainable shoreline protection strategy in Louisiana. Restor Ecol 13:499-506

* Piehler MF, Smyth AR (2011) Habitat-specific distinctions in estuarine denitrification affect both ecosystem function and services. Ecosphere 2:art12

Powers SP, Boyer KE (2014) Marine restoration ecology. In: Bertness MD, Bruno JF, Silliman BR, Stachowicz JJ (eds) Marine community ecology and conservation. Sinauer Associates, Sunderland, MA, p 495-516

Powers SP, Grabowski JH, Roman H, Geggel A, Rouhani S, Oehrig J, Baker M (2017) Consequences of large-scale salinity alteration during the Deepwater Horizon oil spill on subtidal oyster populations. Mar Ecol Prog Ser 576: 175-187

* Reddy CM, Eglington LB, Hounshell A, White HK, Xu L, Gaines RB, Frysinger GS (2002) The West Falmouth oil spill after thirty years: the persistence of petroleum hydrocarbons in marsh sediments. Environ Sci Technol 36: 4754-4760

Rodriguez AB, Fodrie FJ, Ridge JT, Lindquist NL and others (2014) Oyster reefs can outpace sea-level rise. Nat Clim Chang 4:493-497

* Rose KA, Huang H, Justic D, de Mustert K (2014) Simulating fish movement responses to and potential salinity stress from large-scale river diversions. Mar Coast Fish 6: 43-61

* Roth AMF, Baltz DM (2009) Short-term effects of an oil spill on marsh-edge fishes and decapod crustaceans. Estuaries Coasts 32:565-572

Rozas LP (1995) Hydroperiod and its influence on nekton use of the salt marsh: a pulsing ecosystem. Estuaries 18: $579-590$ 
Scyphers SB, Powers SP, Heck KL, Byron D (2011) Oyster reefs as natural breakwaters mitigate shoreline loss and facilitate fisheries. PLOS ONE 6:e22396

Smith CJ, DeLaune RD, Patrick WH Jr, Fleeger JW (1984) Impact of dispersed and undispersed oil entering a gulf coast salt marsh. Environ Toxicol Chem 3:609-616

Soniat TM, Klinck JM, Powell EN, Cooper N and others (2012) A shell-neutral modeling approach yields sustainable oyster harvest estimates: a retrospective analysis of the Louisiana state primary seed grounds. J Shellfish Res 31:1103-1112

Stevens DL, Olsen AR (1999) Spatially restricted surveys over time for aquatic resources. J Agric Biol Environ Stat 4:415-428

Stevens DL, Olsen AR (2004) Spatially balanced sampling of natural resources. J Am Stat Assoc 99:262-278

Syvitski JPM, Vorosmarty CJ, Kettner AJ, Green P (2005) Impact of humans on the flux of terrestrial sediment to the global coastal ocean. Science 308:376-380

Tunnell JW Jr, Dokken QR, Kindinger ME, Thebeau LC (1981) Effects of the Ixtoc I oil spill on the intertidal and subtidal infaunal populations along lower Texas coast

Editorial responsibility: Charles Peterson,

Morehead City, North Carolina, USA barrier island beaches. Proceedings of the 1981 Oil Spill Conference. American Petroleum Institute, Washington, DC, p 467-475

* Turner RE (2006) Will lowering estuarine salinity increase Gulf of Mexico oyster landings? Estuaries Coasts 29: 345-352

*Vitousek PM, Mooney HA, Lubchenco J, Melillo JM (1997) Human domination of Earth's ecosystems. Science 277: 494-499

*Willis JM, Hester MW, Rouhani S, Steinhoff MA, Baker MC (2016) Field assessment of the impacts of Deepwater Horizon oiling on coastal marsh vegetation of Mississippi and Alabama. Environ Toxicol Chem 35: 2791-2797

Zengel S, Bernik BM, Rutherford N, Nixon Z, Michel J (2015) Heavily oiled salt marsh following the Deepwater Horizon oil spill, ecological comparisons of shoreline cleanup treatments and recovery. PLOS ONE 10:e0132324

* zu Ermgassen P, Spalding M, Blake B, Coen L and others (2012) Historical ecology with real numbers: past and present extent and biomass of an imperiled estuarine habitat. Proc R Soc Lond B Biol Sci 279:3393-3400

Submitted: March 2, 2017; Accepted: May 17, 2017

Proofs received from author(s): July 7, 2017 